\title{
Hydrogen production through gasification of whey
}

\author{
Elif Ece Çağlı ${ }^{1}$, Tolga Kaan Kanatlı ${ }^{1,}$ Serkan Karadeniz ${ }^{1}$, Nezihe Ayas ${ }^{1 *}$ \\ ${ }^{1}$ Eskisehir Technical University, Engineering Faculty, Department of Chemical Engineering, 2 Eylul Campus, 26555 Eskisehir, Turkey
}

\begin{abstract}
Hydrogen is one of the clean energy carriers and it is obtained from fossil and renewable energy sources and waste of the food industry. In this study, whey, which is the waste of the cheese factory, was gasified using a high-pressure batch reactor at different temperatures $\left(300,350,400{ }^{\circ} \mathrm{C}\right)$ and an updraft tubular reactor at $\left(650,700^{\circ} \mathrm{C}\right)$. In order to find out suitable gasification conditions, the effect of reaction parameters such as catalyst type $\left(\mathrm{K}_{2} \mathrm{CO}_{3}\right.$ and $\left.\mathrm{NaOH}\right)$, temperature $\left(300-700{ }^{\circ} \mathrm{C}\right)$ and time $(30-120 \mathrm{~min})$ were investigated. The highest hydrogen yield (14.47 $\mathrm{mol} \mathrm{H}_{2} / \mathrm{kg}$ Whey Powder-2) was obtained with 2.51 $\mathrm{M} \mathrm{NaOH}$ at $120 \mathrm{~min}$. reaction time at $400{ }^{\circ} \mathrm{C}$.
\end{abstract}

\section{Introduction}

The energy demand has been increasing with the developing industry. Conventional energy sources, such as coal, petroleum and natural gas are limited and hazardous to the environment. Biomass is a clean alternative energy source that can be used to mitigate environmental pollution through the reduction of greenhouse gas emissions [1]. Production of hydrogen from biomass is divided into two groups as thermochemical (i.e. pyrolysis, gasification, and liquefaction) and biological (i.e. biophotolysis and fermentation) processes [2]. Gasification is one of the thermochemical processes that convert feedstocks into useful gases and chemicals in the presence of a gasification agent (air, oxygen, steam or a mixture of these) [3]. Whey is a yellow-greenish waste liquid formed due to the clotting of milk during the cheese manufacturing process [4]. The compositional difference between whey and whey powder are listed in Table 1 [5].

Table 1. Typical composition of whey and whey powder [5]

\begin{tabular}{|c|c|c|}
\hline Composition (\%) & Whey & Whey Powder \\
\hline Protein & $0.7-0.8$ & $11.0-14.5$ \\
\hline Fat & 0.1 & $1.0-1.5$ \\
\hline Ash & 0.5 & $8.2-8.8$ \\
\hline Lactose & 4.9 & $63.0-75.0$ \\
\hline Water & $93.7-93.8$ & $3.5-5.0$ \\
\hline
\end{tabular}

Most of the work on hydrogen production from whey was done using biological processes such as fermentation [6-9]. Only a single report on hydrogen production through the gasification of whey was found in the literature and no reports on the gasification of whey powder were found. Muangrat et al. investigated alkaline subcritical water gasification of whey powder solution which is $5 \mathrm{~g}$ of whey powder dissolved in $100 \mathrm{~mL}$ of deionized water. Hydrogen peroxide $(1.5 \mathrm{wt} \%)$ was used as an oxidant. The highest hydrogen yield was obtained as $147 \mathrm{mg} \mathrm{H}_{2}$ at $120 \mathrm{~min}, 390{ }^{\circ} \mathrm{C}$ and $1.67 \mathrm{M} \mathrm{NaOH}$ as a catalyst [10].

In this study, the gasification of whey and whey powders was performed to obtain hydrogen-rich gases.

\section{Materials and methods}

\subsection{Materials}

Whey and two types of whey powder were gasified in order to obtain $\mathrm{H}_{2}$ rich gas product (Table 2).

Table 2. The content of whey and WP

\begin{tabular}{|c|c|}
\hline Sample & Content of Whey and WP \\
\hline W & Whey (5\% solid material) \\
\hline WP1 & Whey Powder $(0.05 \%$ fat $)$ \\
\hline WP2 & Whey Powder $(2.34 \%$ fat $)$ \\
\hline
\end{tabular}

Whey was supplied from a dairy products factory in Eskisehir. The powdered samples (WP1 and WP2) were obtained by lyophilization.

\subsection{Equipment}

Whey (W) was gasified in a high temperature, highpressure stainless steel, $500 \mathrm{~mL}$ batch reactor (PARR model 4575). Temperature and mixing speed were controlled with a PARR 4843 control unit. The maximum operating pressure and temperature of the high-pressure batch reactor was 350 bar and $500{ }^{\circ} \mathrm{C}$, respectively. The system consists of a stirrer, gaskets, pressure gauge, and heating system. Whey powder (WP) was gasified in a 316

* Corresponding author: nazcan@eskisehir.edu.tr 
stainless steel updraft tubular reactor with the dimensions of $900 \times 10 \mathrm{~mm}$. The major components of the reactor system are an insulated tubular reactor, a gas-liquid separator, and particle-moisture traps. The lyophilization process was carried out in a lyophilizer (LABCONCO) in order to obtain WP. The fat content was determined by Soxhlet extraction. SRA Technologies Micro Gas Chromatograph ( $\mu$-GC) (T-3000 series) equipped with MS5A (Molecular sieves $5 \AA$ ) and PPQ (PolarPlot Q) columns coupled to thermal conductivity detector (TCD) was used to analyze the product gas.

\subsection{Experimental Study}

\subsubsection{The lyophilization}

To obtain WP, whey was lyophilized for 5 days at $-80{ }^{\circ} \mathrm{C}$, under vacuum (0.180 mbar).

\subsubsection{Determination of fat content}

The fat content of WP was determined by Soxhlet extraction using hexane as a solvent. Extraction was carried out under reflux for 5 hours. Then the solvent was recovered by rotary evaporator under reduced pressure.

\subsubsection{Gasification of whey}

A high-pressure batch reactor was used for the gasification of whey with a $5.6 \%$ solid material content, using $\mathrm{NaOH}$ as a catalyst $(0.83 \mathrm{M}, 1.67 \mathrm{M}, 2.51 \mathrm{M})$ at various temperatures $\left(300,350,400{ }^{\circ} \mathrm{C}\right)$ and reaction times $(60,120 \mathrm{~min}) . \mathrm{NaOH}$ and 1.5 wt. $\% \mathrm{H}_{2} \mathrm{O}_{2}$ as an oxidant was mixed with $100 \mathrm{~mL}$ of whey. After the reaction, the reactor was cooled to room temperature, the product gas was collected in a gas sampling bag and analyzed by a micro-gas chromatographer. The liquid and the solid products were separated by vacuum filtration. Ethyl acetate (EA) was used as the solvent to extract the water-soluble products from the liquid sample. The solvent was removed from the EA-soluble phase using a rotary evaporator and the water content of the aqueous phase was removed through heating.

\subsubsection{Gasification of whey powder}

$3 \mathrm{~g}$ of WP and 20 wt.\% catalyst was dry mixed and added into the reactor. The gasification process was carried out in the presence of $\mathrm{K}_{2} \mathrm{CO}_{3}$ catalyst, at different reaction temperatures $\left(650,700{ }^{\circ} \mathrm{C}\right)$ and reaction times $(30,45$ min). High purity dry air was fed to the reactor as the gasification agent at $3 \mathrm{~L} / \mathrm{h}$ feed rate and at 2 bar pressure. The product gas was collected in a gas sampling bag and its composition was determined using a $\mu-\mathrm{GC}$.

\subsubsection{Gas analysis}

Argon is used as the carrier gas in the MS5A column, that has an injection and column temperature of $90{ }^{\circ} \mathrm{C}$, column pressure of 35 psi, no injection delay and $180 \mathrm{~s}$ analysis time. Helium is used as the carrier gas in the PPQ column, and the operating conditions of the column are $90{ }^{\circ} \mathrm{C}$ injection temperature, $70{ }^{\circ} \mathrm{C}$ column temperature, $30 \mathrm{psi}$ column pressure, $50 \mathrm{~ms}$ injection delay and $180 \mathrm{~s}$ analysis time.

\section{Results and discussions}

\subsection{Gasification of whey}

\subsubsection{Effect of reaction temperature}

Whey was subjected to gasification at various reaction temperatures $\left(300,350\right.$ and $\left.400{ }^{\circ} \mathrm{C}\right)$ and constant reaction time $(120 \mathrm{~min})$ in the presence of $\mathrm{NaOH}$ catalyst and $1.5 \%$ wt. $\mathrm{H}_{2} \mathrm{O}_{2}$ oxidant. The change of product gas component with temperature is given in Fig. 1.

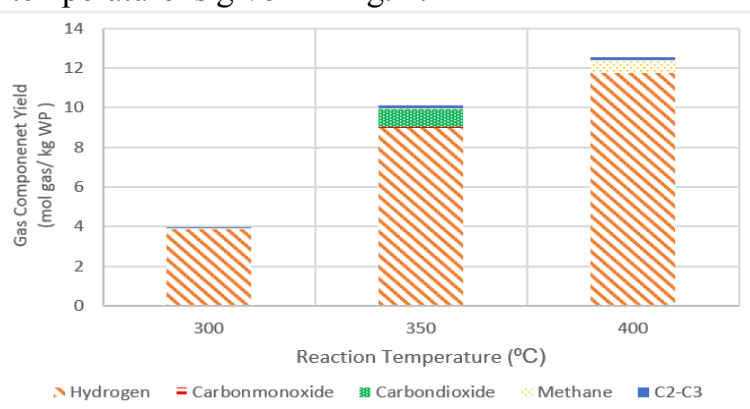

Fig. 1. Effect of reaction temperature on gaseous products (1.67 $\mathrm{M} \mathrm{NaOH}, 120$ min reaction time and $1.5 \%$ wt. $\mathrm{H}_{2} \mathrm{O}_{2}$ )

As it can be seen in Fig. 1, hydrogen yield increases from 3.85 to $11.74 \mathrm{~mol} \mathrm{H}_{2} / \mathrm{kg}$ WP2 with the temperature because of the secondary cracking, water-gas, and hydrocarbon reforming reactions which are endothermic. Taba et al. have encountered similar results in their work on the effect of temperature on the gasification of various feed stock [11].

\subsubsection{Effect of reaction time}

The effect of reaction time on the gasification of whey was investigated at different reaction times $(60,120 \mathrm{~min})$ and reaction temperature $\left(400{ }^{\circ} \mathrm{C}\right)$ in the presence of $\mathrm{NaOH}$ catalyst and $1.5 \%$ wt. $\mathrm{H}_{2} \mathrm{O}_{2}$ as an oxidant (Fig. 2).

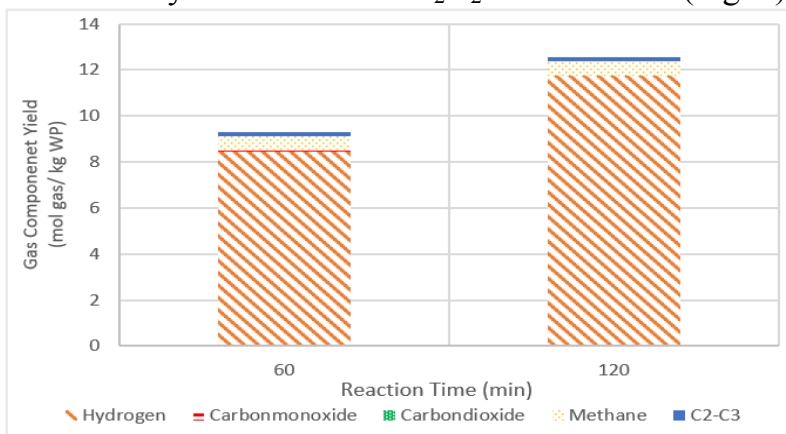

Fig. 2. Effect of reaction time on gaseous products $(1.67 \mathrm{M}$ $\mathrm{NaOH}, 400{ }^{\circ} \mathrm{C}$ reaction temperature and $1.5 \%$ wt. $\mathrm{H}_{2} \mathrm{O}_{2}$ ) 
According to Fig. 2, The hydrogen yield increased greatly from 8.44 to $11.74 \mathrm{~mol} \mathrm{H}_{2} / \mathrm{kg} \mathrm{WP} 2$. Hydrogen yield increased by about $39 \%$ with the reaction time. Muangrat et al determined that an increase of hydrogen yield with increasing reaction time could be explained by the decomposition of heavier carbon-containing hydrocarbon gases taking place at longer reaction times [10].

\subsubsection{Effect of catalyst concentration}

Effect of $\mathrm{NaOH}$ catalyst concentration at constant reaction time $(120 \mathrm{~min})$ and reaction temperature $\left(400{ }^{\circ} \mathrm{C}\right)$ and $1.5 \%$ wt. $\mathrm{H}_{2} \mathrm{O}_{2}$ oxidant was investigated. Component yields are plotted against catalyst concentration in Fig. 3.

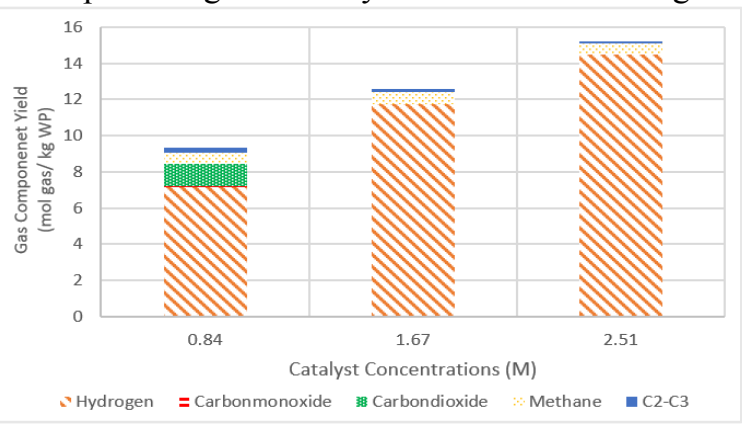

Fig. 3. Effect of catalyst concentration on gaseous products (120 min reaction time, $400{ }^{\circ} \mathrm{C}$ reaction temperature and $1.5 \%$ wt. $\mathrm{H}_{2} \mathrm{O}_{2}$ )

Fig. 3 shows that the highest hydrogen yield (14.47 mol $\mathrm{H}_{2} / \mathrm{kg}$ WP2) was obtained with $2.51 \mathrm{M} \mathrm{NaOH}$. At these conditions, the $\mathrm{CO}_{2}$ yield was zero. Onwudilli et al investigated the effect of $\mathrm{NaOH}$ on hydrothermal gasification. $\mathrm{NaOH}$ promotes the consumption of $\mathrm{CO}$ and captures $\mathrm{CO}_{2}$. When the $\mathrm{NaOH}$ concentration increases, $\mathrm{CO}_{2}$ yield decreases. The presence of $\mathrm{NaOH}$ shifts the water - gas reaction to the forward direction by capturing $\mathrm{CO}_{2}$ and therefore increases the hydrogen yield [12].

\subsection{Gasification of whey powder}

\subsubsection{Effect of WP type}

Two types of WP were gasified in the presence of $20 \mathrm{wt} . \%$ $\mathrm{K}_{2} \mathrm{CO}_{3}$ catalyst, at $30 \mathrm{~min}$. reaction time and $650{ }^{\circ} \mathrm{C}$ reaction temperature.

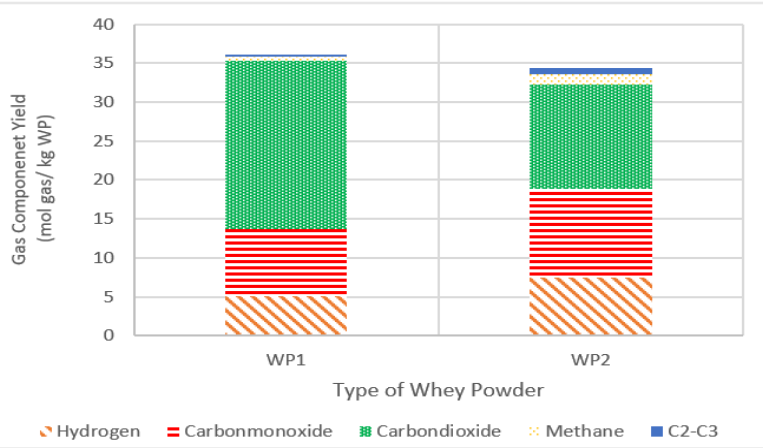

Fig. 4. Effect of WP type on gaseous products ( 30 min reaction time, $20 \mathrm{wt} . \% \mathrm{~K}_{2} \mathrm{CO}_{3}$ catalyst and $650{ }^{\circ} \mathrm{C}$ reaction temperature)
As shown in Fig. 4, The hydrogen yield increased from $5.12 \mathrm{~mol} \mathrm{H}_{2} / \mathrm{kg}$ WP1 to $7.41 \mathrm{~mol} \mathrm{H}_{2} / \mathrm{kg}$ WP2. Similarly, $\mathrm{CO}$ and $\mathrm{CH}_{4}$ yields increased from $8.58 \mathrm{~mol}$ $\mathrm{CO} / \mathrm{kg} \mathrm{WP} 1$ to $11.46 \mathrm{~mol} \mathrm{CO} / \mathrm{kg} \mathrm{WP} 2$ and $0.58 \mathrm{~mol}$ $\mathrm{CH}_{4} / \mathrm{kg} \mathrm{WP} 1$ to $1.43 \mathrm{~mol} \mathrm{CH}_{4} / \mathrm{kg} \mathrm{WP} 2$, respectively. The increase of hydrogen yield can be associated with the fat content that contains high hydrogen and carbon. The fat content of WP1 and WP2 are $0.05 \%$ and $2.34 \%$, respectively. The gasification of WP2 powder yielded more hydrogen than the gasification of WP1.

\subsubsection{Effect of reaction time}

The effect of different reaction times (30 min and $45 \mathrm{~min}$ ) on the gasification of WP2 at $650{ }^{\circ} \mathrm{C}$ and in the presence of 20 wt. $\% \mathrm{~K}_{2} \mathrm{CO}_{3}$ was investigated. Component yields are plotted against the reaction times in Fig. 5.

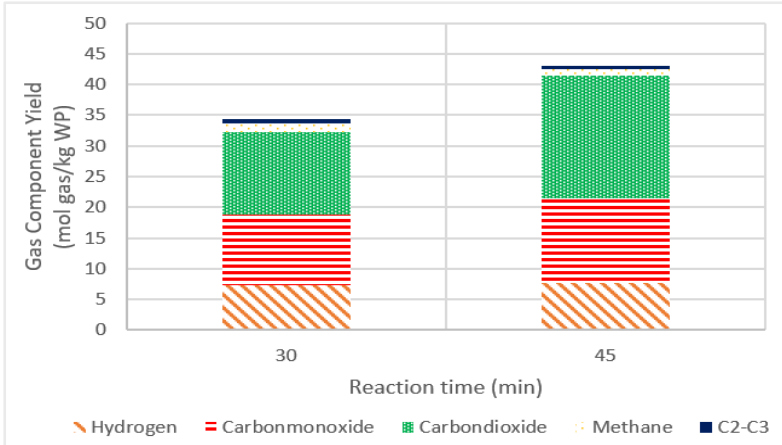

Fig. 5. Effect of reaction times on gaseous products $\left(650^{\circ} \mathrm{C}\right.$ reaction temperature and $20 \mathrm{wt} . \% \mathrm{~K}_{2} \mathrm{CO}_{3}$. catalyst)

It can be seen in Fig. 5 that as a result of the increase in reaction time from $30 \mathrm{~min}$ to $45 \mathrm{~min}, \mathrm{H}_{2}, \mathrm{CO}$, and $\mathrm{CO}_{2}$ gas yields were enhanced from 7.41 to $7.71 \mathrm{~mol} \mathrm{H}_{2} / \mathrm{kg}$ WP2, 11.46 to $13.78 \mathrm{~mol} \mathrm{CO} / \mathrm{kg}$ WP2 and 13.36 to 19.99 mol $\mathrm{CO}_{2} / \mathrm{kg}$ WP2, respectively. There is no significant difference between $30 \mathrm{~min}$ and $45 \mathrm{~min}$, therefore the reaction time was chosen as 30 minutes.

\subsubsection{Effect of reaction temperature}

The effect of different reaction temperatures $\left(650{ }^{\circ} \mathrm{C}\right.$ and $700^{\circ} \mathrm{C}$ ) on the gasification of WP at $30 \mathrm{~min}$ reaction time and in the presence of 20 wt. $\% \mathrm{~K}_{2} \mathrm{CO}_{3}$ was also investigated. Component yields are plotted against the reaction temperatures in Fig. 6.

Fig. 6. Effect of reaction temperature on gaseous products (30 min reaction time and $20 \mathrm{wt} . \% \mathrm{~K}_{2} \mathrm{CO}_{3}$ )

According to Fig. 6, there is no significant difference in the hydrogen yield obtained at 650 and $700{ }^{\circ} \mathrm{C}$. While $\mathrm{CH}_{4}$ yield decreases with temperature, $\mathrm{CO}$ and $\mathrm{CO}_{2}$ yield increases. The yield of $\mathrm{CO}$ increases more than $\mathrm{CO}_{2}$ yield. It can be explained with the boudouard reaction, shifting in the forward direction with increasing temperature due to it being an endothermic reaction [13].

\section{Conclusion}


In this study, the gasification of whey and whey powder was investigated in order to obtain hydrogen-rich gas. The gasification of two types of WP was performed in an updraft tubular reactor. Two types of whey (5 wt.\% solid content) were lyophilized to obtain the WP for gasification. The highest hydrogen yield $\left(7.77 \mathrm{~mol} \mathrm{H}_{2} / \mathrm{kg}\right.$ WP) was obtained from WP2, which has a higher fat content than WP1, at $700{ }^{\circ} \mathrm{C}$, with $20 \mathrm{wt} . \% \mathrm{~K}_{2} \mathrm{CO}_{3}$ and 30 min reaction time. WP2 produced the highest amount of hydrogen in the WP gasification experiments, therefore the direct gasification of whey in the high-pressure batch reactor was carried out using its whey sample. The highest hydrogen yield (14.47 $\mathrm{mol} \mathrm{H}_{2} / \mathrm{kg} \mathrm{WP}$ ) was obtained at $400{ }^{\circ} \mathrm{C}$, with a reaction time of $120 \mathrm{~min}$, using $2.51 \mathrm{M} \mathrm{NaOH}$ as a catalyst.

The gasification of WP solution (5 wt.\% WP dissolved in deionized water) was investigated in the literature. The highest amount of hydrogen $\left(147 \mathrm{mg} \mathrm{H}_{2}\right)$ was obtained at $120 \mathrm{~min}, 390{ }^{\circ} \mathrm{C}, 1.67 \mathrm{M} \mathrm{NaOH}$ as a catalyst and 1.5 wt. $\% \mathrm{H}_{2} \mathrm{O}_{2}$ [10]. In this study, whey with a 5.6 wt.\% solid content was gasified at the same conditions and $133.4 \mathrm{mg} \mathrm{H}_{2}$ was obtained. Hydrogen yield decreased by about $10.5 \%$ when whey was used directly, instead of the WP solution. Hydrogen yield was lower because whey has more impurities. It is concluded that the $10.5 \%$ decrease in hydrogen yield is preferable to the energy costs of pasteurization and spray drying processes.

\section{References}

1. W.X. Peng, L.S. Wang, M. Mirzaee, H. Ahmadi, M.J. Esfahani, S. Fremaux, Energy Convers. Manag. 135, 270-273 (2017)

2. E.R. Widjaya, G. Chen, L. Bowtell, C. Hills, Renew. Sust. Energ. Rev. 89, 184-193 (2018)

3. P. Basu, Biomass Gasification and Pyrolysis Practical Design and Theory, (Elsevier Inc., Canada, 2010)
4. C.I. Onwulata, P.J. Huth, Whey Processing, Functionality and Health Benefits. (Wiley-Blackwell IFT Press, USA, 2008)

5. M. Guo, Whey Protein Production, Chemistry, Functionality, and Applications. (John Wiley \& Sons Ltd, USA, 2019)

6. F. Kargi, N.S. Eren, S. Ozmichi, Int. J. Hydrogen Energ. 37, 8338-8342 (2011)

7. F. Kargi, N.S. Eren, S. Ozmichi, Int. J. Hydrogen Energ 37, 2260-2266 (2012)

8. V. Perna, E. Castello, J. Wenzel, C. Zampol, D.M. Fontes Lima, L. Borzacconni, M.B. Varesche, M. Zaiat, C. Etchebehere, Int. J. Hydrogen Energ. 38, 54-62 (2013)

9. B.C. Gomes, P.R.F. Rosa, C. Etchebehere, E.L. Silva, M.B. AmancioVaresche, Int. J. Hydrogen Energ. 40, 8650-8660 (2015)

10. R. Muangrat, J.A. Onwudili, P.T. Williams, Bioresour. Technol. 102, 6331-6335 (2011)

11. L.E. Taba, M.F. Irfan, W. A. M. W. Daud, M.H. Chakrabarti, Renew. Sust. Energ. Rev. 16, 55845596 (2012)

12. J.A. Onwudilli, P.T. Williams, Int. J. Hydrogen Energ. 34, 5645-5656 (2009)

13. M. He, B. Xiao, Z. Hu, S. Liu, X. Guo, S. Luo, Int. J. Hydrogen Energ. 34, 1342-1348 (2009) 